\title{
Review \\ Phyto-oestrogens and breast cancer chemoprevention
}

Jane L Limer and Valerie Speirs

\author{
Molecular Medicine Unit, University of Leeds, St James's University Hospital, Leeds, UK \\ Corresponding author: V Speirs (e-mail v.speirs@leeds.ac.uk) \\ Published: 18 March 2004 \\ Breast Cancer Res 2004, 6:119-127 (DOI 10.1186/bcr781) \\ (C) 2004 BioMed Central Ltd (Print ISSN 1465-5411; Online ISSN 1465-542X)
}

\begin{abstract}
Phyto-oestrogens are polyphenol compounds of plant origin that exhibit structural similarity to the mammalian steroid hormone 17ß-oestradiol. In Asian nations the staple consumption of phytooestrogen-rich foodstuffs correlates with a reduced incidence of breast cancer. Human dietary intervention trials have noted a direct relationship between phyto-oestrogen ingestion and a favourable hormonal profile associated with decreased breast cancer risk. However, these studies failed to ascertain the precise effect of dietary phyto-oestrogens on the proliferation of mammary tissue. Epidemiological and rodent studies crucially suggest that breast cancer chemoprevention by dietary phyto-oestrogen compounds is dependent on ingestion before puberty, when the mammary gland is relatively immature. Phyto-oestrogen supplements are commercially marketed for use by postmenopausal women as natural and safe alternatives to hormone replacement therapy. Of current concern is the effect of phyto-oestrogen compounds on the growth of pre-existing breast tumours. Data are contradictory, with cell culture studies reporting both the oestrogenic stimulation of oestrogen receptor-positive breast cancer cell lines and the antagonism of tamoxifen activity at physiological phyto-oestrogen concentrations. Conversely, phyto-oestrogen ingestion by rodents is associated with the development of less aggressive breast tumours with reduced metastatic potential. Despite the present ambiguity, current data do suggest a potential benefit from use of phyto-oestrogens in breast cancer chemoprevention and therapy. These aspects are discussed.
\end{abstract}

Keywords: breast cancer, estrogen receptor, isoflavone, phyto-oestrogen

\section{Introduction}

The current mortality rate for premenopausal breast cancer is approximately fourfold higher in the Western World than in Far East Asian nations [1]. Migrants from Asia to the USA typically acquire a breast cancer risk associated with their host nation by the second generation, suggesting a direct influence of environmental rather than genetic factors $[2,3]$. The reduced prevalence of breast cancer in Far East Asian nations directly correlates with the consumption of a staple diet that is abundant in soy [4]. Asian populations consume an approximate mean daily soy intake of $10-50 \mathrm{~g}$, declining to just $1-3 \mathrm{~g}$ in the USA. The recent adoption of a more westernized diet correlates with an increased breast cancer incidence in urban areas of Japan, Singapore and China [5]. Soycontaining foods are an abundant source of phyto- oestrogens, and research suggests that these compounds may exhibit chemoprotectant activity against a number of human cancers, including colon carcinoma and hormonedependent cancers of the breast and prostate [6]. This report focuses on the putative chemopreventive role of phyto-oestrogens in breast cancer, providing a comprehensive review of the published literature to date.

Phyto-oestrogen classification and metabolism Phyto-oestrogens may be classified into a number of principal groups [2,7-9]: the isoflavones (genistein, daidzein, biochanin A), the lignans (enterolactone, enterodiol), the coumestans (coumestrol) and the stilbenes (resveratrol). As illustrated in Fig. 1, all are polyphenols sharing structural similarity with the principal mammalian oestrogen $17 \beta$-oestradiol. Shared features include the presence of a

$\mathrm{DMBA}=$ 7,12-dimethylbenz(a)anthracene; EGC = epigallocatechin; EGF = epidermal growth factor; EGCG = epigallocatechin-3 gallate; ER = oestrogen receptor; ERE = oestrogen response element; HRT = hormone replacement therapy; IGF = insulin-like growth factor; SRC = steroid receptor coactivator; TGF $=$ transforming growth factor. 


$$
\text { Oestrogens }
$$

(a)<smiles>CC12CCC3c4ccc(O)cc4CCC3C1CCC2O</smiles>

$17-\beta$ oestradiol

Lignans

(d)<smiles>O=C1OCC(Cc2cccc(O)c2)C1Cc1cccc(O)c1</smiles>

Enterolactone (b)<smiles>CC/C(=C(\CC)c1ccc(O)cc1)c1ccc(O)cc1</smiles>

Diethylstilbestrol

(e)<smiles>OCC(CO)Cc1cccc(O)c1</smiles>

Enterodiol
Stilbenes

(c)<smiles>Oc1ccc(/C=C/c2cc(O)cc(O)c2)cc1</smiles>

Resveratrol

Coumestans

(f)<smiles></smiles>

Coumestrol

\section{Isoflavones}

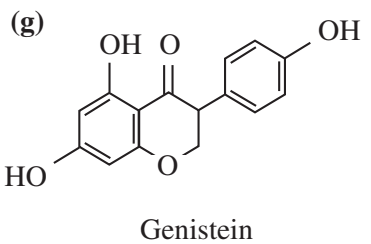

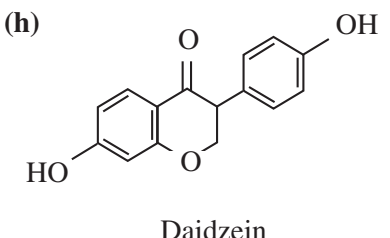<smiles>COc1ccc(C2COc3cc(O)cc(O)c3C2=O)cc1</smiles>

Biochanin A

Structural comparison of the natural and synthetic oestrogens (a) $17 \beta$-oestradiol and (b) diethylstilbestrol with the principal classes of phyto-oestrogen: the stilbene (c) resveratrol, lignan compounds (d) enterolactone and (e) enterodiol, the coumestan (f) coumestrol, and isoflavones (g) genistein, (h) daidzein and (i) biochanin A.

pair of hydroxyl groups and a phenolic ring, which is required for binding to the oestrogen receptor (ER) subtypes $\alpha$ and $\beta$. The position of the hydroxyl groups appears to be important in determining ER binding ability and transcriptional activation, with maximal potency achieved at positions four, six and seven [10-12]. The isoflavones are naturally found in soybeans and soy-based food products, including tofu, soy milk, textured soy protein and miso. Lignans are present in flaxseed and most fruit and vegetables, and the predominant dietary source of stilbenes is peanuts, grapes and red wine $[7,13]$. The coumestans are much less frequently consumed within the human diet, but they are more potent activators of ER signalling pathways than are the isoflavones genistein and daidzein $[10,14]$. By contrast, the stilbene resveratrol is the least potent activator of ER signalling [11].

The isoflavones are present in soy as $\beta$-glucosides. Metabolism by the gastrointestinal microflora yields a number of metabolites including equol and $\mathrm{O}$-desmethylangolensin. Parental compounds and their metabolites are absorbed into the bloodstream, becoming rapidly detectable concentrations are considerably elevated in Asian populations as compared with in Western ones. A recent comparison of Japanese and UK females revealed an almost 20-fold increase in plasma genistein levels in the Japanese cohort, and daidzein concentrations were similarly elevated by 18-fold [20]. Plasma isoflavone concentrations may accumulate to approximately 100- to 1000fold higher than endogenous oestradiol levels following the ingestion of soy-rich meal. However, research suggests a decreased ER binding affinity of isoflavone compounds as compared with the mammalian oestrogens $[9,10,21,22]$. Competition binding assays revealed a 50 fold lower binding affinity of genistein for cytoplasmic ER sites as compared with $17 \beta$-oestradiol [23].

The complete metabolic activation of soy isoflavones is proposed to occur locally within target tissue. In support of this hypothesis, the analysis of tissue culture supernatants from genistein and biochanin A treated MCF-7 and T47-D cells revealed the presence of hydroxylated and methylated isoflavone metabolites [24]. Current research suggests a role for the CYP family of cytochrome P450 enzymes in the intratumour metabolism of phyto- 
oestrogen compounds $[25,26]$. The CYP1B1 enzyme is expressed in a wide range of human tumour types, including breast [27]; however, expression is absent within normal tissue. CYP1B1 is proposed to catalyze the hydroxylation of resveratrol to yield the related stilbene piceatannol [26]. Piceatannol is a tyrosine kinase inhibitor with antileukaemic properties, which differs in structure from resveratrol by the presence of an additional hydroxyl group. A number of plant flavonoids are also putative substrates for the CYP family of enzymes [25]. Maubach and coworkers [28] recently reported the use of highperformance liquid chromatography to quantify isoflavones in normal breast biopsy tissue following consumption of soy for 5 consecutive days. Equol concentrations were approximately fivefold higher in the breast tissue homogenates than in serum, providing further evidence for the metabolism of phyto-oestrogen compounds within mammary tissue.

\section{Role of phyto-oestrogens in breast cancer}

Serum concentrations of $17 \beta$-oestradiol are approximately $40 \%$ lower in Asian women than in their Caucasian counterparts [29]. A low lifetime exposure to oestrogen is associated with a reduced risk for breast cancer. Human dietary intervention studies revealed a direct association between the modest consumption of soy products and a reduction in circulating steroid hormone levels. Daily consumption of $154 \mathrm{mg}$ isoflavones for the duration of a single menstrual cycle correlated with substantially decreased plasma concentrations of $17 \beta$-oestradiol and progesterone in a cohort of premenopausal women [18]. A longer term study conducted by Kumar and coworkers [30] similarly reported a moderate decrease in serum oestradiol and oestrone levels following daily ingestion of $40 \mathrm{mg}$ isoflavones for 3 months. Menstrual cycle length was increased by 3.52 days, and the follicular phase of the cycle was extended by 1.46 days. Increased menstrual cycle length may serve to reduce the total number of cycles per lifetime, therefore decreasing the total exposure of breast epithelia to endogenous oestrogens. Conversely, a year-long dietary intervention trial involving 34 premenopausal women failed to reveal a significant effect of $100 \mathrm{mg} /$ day isoflavone consumption either on menstrual cycle length or on serum levels of various steroid hormones, including oestrone, oestradiol and progesterone [19].

As a possible explanation for these contradictory data, a study conducted by Duncan and coworkers [31] revealed differential hormonal effects of soy isoflavones depending on the ability to excrete the daidzein metabolite equol. Daily ingestion of $10 \mathrm{mg}$ soy protein by premenopausal equol excretors resulted in a hormonal profile associated with reduced breast cancer risk, characterized by lowered plasma levels of oestrone, oestrone-sulphate and testosterone. Hormone levels, however, remained unchanged in the equol nonexcretors after soy ingestion.
The reduction in steroid hormone levels by phytooestrogens is proposed to occur via the direct regulation of $17 \beta$-oestradiol biosynthesis and metabolism. Phytochemicals isolated from vegetable extracts effectively suppress the activity of the aromatase enzymes, which are responsible for conversion of androgens to oestrogens [32]. Isoflavone concentrations of $1-10 \mu \mathrm{mol} / \mathrm{l}$ similarly reduced by $50 \%$ the activity of the oestradiol biosynthetic enzymes $3 \beta$-hydroxysteroid dehydrogenase and $17 \beta$ hydroxysteroid dehydrogenase [10]. The daily ingestion of $113-202 \mathrm{mg}$ isoflavones by premenopausal women correlated with a $40 \%$ increase in the urinary excretion of 2-hydroxyoestrone, a putative anticancer metabolite of $17 \beta$-oestradiol [33]. The above studies thus suggest a dual chemoprotectant mechanism of soy, in which the isoflavones suppress steroid hormone biosynthesis while promoting the metabolism of oestradiol to the protective 2-hydroxylated metabolites.

Despite their apparent effect on endogenous hormone levels, the role of phyto-oestrogens in breast cancer initiation and development is unclear. Few studies to date have addressed the effects of long-term phyto-oestrogen exposure in humans. Daily dietary supplementation with $45 \mathrm{mg}$ soy isoflavone for 14 days correlated with increased proliferation of normal breast epithelia in a group of 48 premenopausal women [16]. Expression of the ER target protein progesterone receptor was upregulated, suggesting an oestrogenic effect. An identical trial using a larger cohort of 84 premenopausal women conversely found no significant effect of soy consumption on the proliferation of normal breast tissue [17]. A number of recent epidemiological studies similarly failed to correlate soyfood consumption with reduced breast cancer risk. A Japanese prospective study conducted in a cohort of approximately 35,000 women [34] revealed no significant association between soy consumption during adulthood and breast cancer incidence. The retrospective analysis of soy food intake in a multiethnic cohort of non-Asian breast cancer patients and control individuals residing in the USA similarly failed to correlate soy intake with breast cancer risk [35].

Increasing epidemiological evidence suggests that the chemoprotectant effects of phyto-oestrogens are dependent on lifelong exposure from childhood. A retrospective study revealed decreased soyfood intake during adolescence in a cohort of 1459 Chinese breast cancer patients, as compared with age-matched control individuals [36]. Daily soy consumption between the ages of 13 and 15 was estimated at $6.45 \mathrm{~g}$ in the patient group, increasing to $7.23 \mathrm{~g}$ in the control cohort. A potential flaw in the study, however, concerns the ability of women up to the age of 64 years to recall accurately the precise soyfood quantities consumed many years earlier during adolescence. These observations may nonetheless explain the apparent lack of a growth inhibitory effect of soy isoflavones in the adult 
dietary intervention studies discussed above. Isoflavones are detectable in breast milk following soy consumption [15], implying that the lower breast cancer incidence in Asian countries may be attributable to phyto-oestrogen exposure from birth via breast-feeding. Rodent studies have accordingly revealed the effective transfer of genistein from maternal milk to offspring [37].

\section{Rodent breast cancer models}

Most available information regarding the effects of phytooestrogens on tumour initiation and the growth of preexisting tumours is derived from rodent studies. A number of similarities do exist between mammary gland development in rodents and humans. In both species the differentiation of breast tissue to form lobules and terminal end-bud structures occurs prepubertally. Further maturation does take place throughout adulthood, giving rise to alveolar buds, which become alveoli during pregnancy and lactation [38].

Rodent dietary intervention studies using phyto-oestrogens have reported chemopreventive activities when feeding is initiated before puberty, at a time when the mammary gland is undergoing development [3,38-40]. The consumption of a resveratrol-supplemented diet by adolescent rats served to decrease sensitivity to the chemical carcinogens 7,12-dimethylbenz(a)anthracene (DMBA) and N-methyl-Nnitrosaurea $[39,40]$. DMBA treatment induced mammary tumours in $45 \%$ of the resveratrol-treated rodents, increasing to $75 \%$ in the group receiving a control diet. An extended tumour latency period in excess of 3 weeks was observed in the resveratrol treatment groups, with the resultant tumours retaining a more differentiated morphology as compared with control animals $[18,39]$. Resveratrol consumption was also associated with the reduced mammary expression of a number of proteins that are putatively involved in malignant progression, including cyclo-oxygenase-2, matrix metalloprotease- 9 and nuclear factor- $\kappa \mathrm{B}$. Similar findings have been noted in prepubertal rats fed an isoflavone-containing diet before tumour initiation using DMBA. Despite having no effect on mammary tumour incidence, soy isoflavone consumption was associated with an increased tumour latency period. The resultant tumours excised from the soy-fed animals were smaller in size and exhibited a more differentiated phenotype compared with control animals [42].

It has been proposed that phyto-oestrogens protect against cancer development in adolescent rodents by promoting maturation of the mammary gland. Analysis of breast tissue from prepubertal rats injected with genistein revealed a decrease in the number of immature terminal end-buds, together with an increase in the more differentiated lobules type II [38]. Genistein treatment of human breast cancer cell lines has similarly been found to induce the expression of a number of maturation markers, including casein, lipid droplets and intercellular adhesion molecule-1 [43].

The effect of soy isoflavones on spontaneous tumour development was recently investigated using neu-ErbB2 over-expressing transgenic mice, which characteristically develop multiple mammary tumours during adulthood [40]. Tumour initiation was temporarily delayed following the consumption of an isoflavone mix, but no chemoprotective effects were observed in mice consuming either genistein or daidzein in isolation. An equal rate of tumour growth was noted in the control and treatment groups, although the isoflavone group exhibited a lower incidence of lung metastases [40]. Antimetastatic activities of the isoflavones were similarly revealed in a study in which mice were fed an isoflavone-supplemented diet before injection with the metastatic 4526 mammary carcinoma cell line [44]. The isoflavone diet was continued following surgical excision of the resultant mammary tumour at a size of $1.0 \mathrm{~cm}$ diameter. Both the incidence and size of macroscopically detectable lung metastases were significantly reduced in the soy-fed mice, suggesting a potential clinical application of soy isoflavones in the prevention of metastasis. Putative anticancer mechanisms of soy and isolated phyto-oestrogen compounds using in vitro and in vivo breast cancer models is summarized in Table 1.

\section{Phyto-oestrogens and tamoxifen}

The selective ER modulator tamoxifen is used clinically in the adjuvant treatment of oestrogen-dependent breast cancer. The drug is also administered as a prophylactic to individuals who are at high risk for developing the disease $[45,46]$. Side effects associated with tamoxifen therapy include menopause-like symptoms such as hot flushes, joint pain, sleep disorders and depression, which may be reduced by the use of hormone replacement therapy (HRT) [47,48]. Long-term HRT is associated with an increased risk for mammary carcinogenesis, and its use by breast cancer patients is therefore discouraged. As a natural alternative, patients may self-medicate with soy isoflavone supplements to alleviate the tamoxifen-induced menopausal symptoms [49]. Published literature regarding the ingestion of dietary phyto-oestrogens by breast cancer patients and survivors is, however, controversial [50,51].

The consumption of genistein by athymic mice antagonized the ability of tamoxifen to inhibit the proliferation of oestrogen-dependent mammary tumours [52]. Tumour suppression by tamoxifen correlated with decreased expression of the ER-inducible genes presenelin-2 ( $p S 2)$ and cyclin D1. Tumour growth was significantly enhanced in mice simultaneously exposed to tamoxifen and genistein, whereas levels of pS2 and cyclin D1 expression were increased. Physiological concentrations of genistein were similarly found to reverse the antagonistic effects of 4-hydroxytamoxifen on ER signalling 
Table 1

\begin{tabular}{|c|c|c|}
\hline Phyto-oestrogen & Cellular effect & Proposed mechanism \\
\hline \multicolumn{3}{|l|}{ Cell culture studies } \\
\hline \multirow[t]{6}{*}{ Genistein } & Growth inhibition & $\downarrow$ EGF receptor activity [23] \\
\hline & & Induction of cell differentiation [43] \\
\hline & & $\downarrow$ AP-1 activity, $\downarrow$ ERK phosphorylation [58] \\
\hline & & 个p21WAF1 [59] \\
\hline & & 个TGF- $\beta$ synthesis [75] \\
\hline & Induction of apoptosis & 个Bax, $\uparrow$ p53 [67] \\
\hline Biochanin A & Growth inhibition & $\downarrow$ ER \\
\hline \multirow[t]{2}{*}{ Resveratrol } & Growth inhibition & $\downarrow$ NF-KB activation [39] \\
\hline & & $\uparrow p 21^{W A F} 1[66,69]$ \\
\hline (-)-Epigallocatechin & Induction of apoptosis & $\downarrow \mathrm{Bcl}-2, \uparrow \mathrm{Bax}[70]$ \\
\hline Epigallocatechin-3 gallate & Growth inhibition & $\downarrow$ Her-2/neu signalling [71] \\
\hline \multicolumn{3}{|l|}{ Rodent models } \\
\hline Genistein & Mammary tumour suppression & Induction of terminal differentiation [38] \\
\hline Resveratrol & Mammary tumour suppression & $\downarrow$ NF-KB activation [39] \\
\hline Soy isoflavone extract & Mammary tumour suppression & $\downarrow$ ER- $\alpha, \downarrow P R[42]$ \\
\hline Isoflavone mix & Reduced metastases & Not defined $[40,44]$ \\
\hline
\end{tabular}

$\downarrow$ and $\uparrow$ indicate a respective reduction or increase in protein levels or activity. AP, activator protein; EGF, epidermal growth factor; ER, oestrogen receptor; ERK, extracellular signal-related kinase; NF-אB, nuclear factor- $\mathrm{KB}$; TGF, transforming growth factor.

pathways [53], promoting the binding of ER- $\alpha$ to the positively acting steroid receptor coactivator (SRC)-1. A recent tissue culture study conversely reported a synergistic antiproliferative effect of tamoxifen and genistein [54]. The proliferation of a panel of dysplastic and cancerous breast cell lines was inhibited by tamoxifen in a dose-dependent manner, and growth was more potently suppressed by combined treatment with tamoxifen and genistein.

\section{Hormone-dependent mechanisms of phyto-oestrogen action}

Oestrogen signalling typically involves the diffusion of ligand through the cell cytoplasm and subsequent binding to the nuclear receptor subtypes ER- $\alpha$ and ER- $\beta$. Ligandbound receptors dimerise and associate with oestrogen response element (ERE) and activator protein-1 element located in the promoter region of target genes, thereby activating transcription. The association between receptor dimers and DNA response elements is enhanced by the binding of cofactor proteins, such as amplified in breast cancer-1, thyroid hormone receptor-associated protein, SRC-1, glutamate receptor interacting protein-1 and translation initiation factor-2 [55]. Examples of EREinduced genes include $P R, c-f o s, b c l-2$ and cathepsin $D$, whereas $p S 2$ and cyclin $D 1$ are transcribed via the activator protein-1 response element.
In breast carcinoma cell lines containing functional ER subtypes the isoflavones exert a biphasic growth effect, stimulating cellular proliferation at concentrations below $5 \mu \mathrm{mol} / \mathrm{l}$ and inhibiting growth in a dose-dependent manner at elevated doses [23,43,56,57]. Growth inhibition correlates with decreased DNA synthesis and cell cycle arrest at the $\mathrm{G}_{2} / \mathrm{M}$ checkpoint [23,54,56,58-60]. Current research suggests a principal signalling role of ER- $\beta$ in response to isoflavone exposure [61]. Whereas 17 $\beta$ oestradiol binds to ER- $\alpha$ and ER- $\beta$ with equal affinity, the soy isoflavones selectively associate with ER- $\beta$ [62]. Receptor binding assays revealed an eightfold to 16-fold increase in the affinity of genistein, daidzein and biochanin A for ER- $\beta$ as compared with ER- $\alpha$ [63]. In ER-negative breast cancer cells transfected to express ER- $\alpha$ alone, genistein was only weakly able to stimulate gene transcription through the ERE. By contrast, genistein effectively bound to ER- $\beta$ and promoted the association of cofactor proteins, thereby regulating downstream ER- $\beta$ mediated gene transcription [62]. The preferential binding affinity of genistein for ER- $\beta$ similarly resulted in a respective 12,000-fold and 33 -fold increase in the recruitment of translation initiation factor-2 and SRC-1a to ER- $\beta$ as compared with ER- $\alpha$ [22]. An enhanced transcriptional activity in response to genistein was, however, noted in cells transfected to express both 
receptor subtypes as compared with cells solely expressing ER- $\beta$ [64]. Although ER- $\alpha$ is itself unable to mediate isoflavone signal transduction, it was postulated that the presence of the receptor subtype may enhance ER- $\beta$ signalling via the formation of ER- $\alpha / \beta$ heterodimers. These observations imply that the precise tissue-specific effects of the soy isoflavones are dependent on the expression levels and ratios of ER- $\alpha$ and ER- $\beta$. The various cofactors are similarly expressed in a tissue-specific manner, therefore further influencing the cellular response to dietary phyto-oestrogens.

The stilbene resveratrol is structurally similar to the synthetic oestrogen diethylstilbestrol. Treatment of breast cancer cell lines with resveratrol represses proliferation in a dose-dependent manner, inducing $G_{2} / M$ phase cell cycle arrest [39]. Resveratrol exhibits a relatively weak ERbinding affinity as compared with oestradiol [65]; however, unlike the soy isoflavones, it is able to bind to both ER- $\alpha$ and ER- $\beta$ with equal affinity. In cells transfected to express either ER- $\alpha$ or ER- $\beta$ resveratrol was found to act as an agonist for both receptor subtypes, stimulating ERE transcriptional activity through either ER- $\alpha$ or ER- $\beta$ alone [21]. Similar agonist activity was observed in MCF-7 breast cancer cells, which predominantly express the ER- $\alpha$ isoform. Resveratrol induced the dose-dependent activation of ERE-mediated transcription, also upregulating the expression of the ER target genes $p S 2$ and $P R$ [65]. Recent studies proposed that the cell cycle inhibitor protein $221^{\text {WAF1 }}$ is a potential downstream target of resveratrol-induced ER signalling pathways [66]. The treatment of ER- $\alpha$-expressing breast cancer cells with resveratrol resulted in a 23-fold increase in p21WAF1 gene expression, as determined by cDNA microarray analysis. The resveratrol-mediated induction of p21WAF1 was blocked by treatment with the pure anti-oestrogen $\mathrm{ICl}$ 182,780 , confirming $p 21^{\text {WAF1 }}$ gene regulation as an ERmediated event.

\section{Hormone-independent mechanisms}

At concentrations in excess of $25 \mu \mathrm{mol} / /$, the soy isoflavones are capable of inducing apoptosis in human breast cancer cells [23,67-69]. ER-negative cell lines retain sensitivity to the apoptotic effects of soy isoflavones, thereby confirming that apoptosis occurs in a hormone-independent manner. Apoptosis was effectively induced in the ER- $\alpha$-negative MDA-MB-231 breast cancer cell line by genistein and daidzein concentrations of $50-100 \mu \mathrm{mol} / \mathrm{l}[59,60]$. In MCF-7 cell cultures the induction of cell death by treatment with genistein coincided with the increased expression of the proapoptotic proteins Bax and p53 [67]. Breast cancer cell lines expressing mutant p53 also undergo apoptosis in response to phytooestrogen treatment, thereby implying apoptosis induction by both p53-dependent and p53-independent mechanisms principally found in green tea and is proposed to have anticancer properties. Treatment of p53-mutant breast cancer cells with $100 \mu \mathrm{mol} / \mathrm{l}$ EGC induced a $40 \%$ increase in apoptosis, correlating with increased Bax expression and reduced levels of the antiapoptotic protein Bcl-2 [70]. EGC-induced apoptosis was abolished following treatment with anti-Fas neutralizing antibodies or caspase inhibitors, suggesting the involvement of Fas signalling pathways. Although phyto-oestrogen compounds are effective inducers of apoptosis in cell culture models, it is unlikely that plasma isoflavone concentrations would accumulate to the required levels for the activation of apoptotic pathways in vivo. It is estimated that plasma phyto-oestrogen concentrations may reach a maximum of $2-4 \mu \mathrm{mol} / /$ following the moderate consumption of soy products $[15,52]$, although it is possible that higher levels may be present in target tissues. In a recently reported study, equol concentrations within breast tissue were found to exceed serum levels; however, the reverse was true for genistein and daidzein [28]. A recent in vitro study [68] revealed the flavone baicalein to be a more potent inducer of apoptosis than genistein. Baicalein is isolated from the plant Scutellariae radix and is a common ingredient in herbal tea preparations. A concentration of $10 \mu \mathrm{mol} / /$ baicalein induced significant cell death in MCF-7 cell cultures, suggesting baicalein as a potentially useful pharmacological agent in breast cancer therapy.

Dietary phyto-oestrogens are capable of inhibiting the proliferation of hormone-independent breast cell lines $[43,54,58,69]$. It has been proposed that growth inhibition in the absence of functional ER occurs via the inhibition of tyrosine kinase activity. The protein tyrosine kinases are involved in a number of growth factor signalling pathways, including transforming growth factor (TGF)- $\alpha$, insulin-like growth factor (IGF)-I, IGF-II and epidermal growth factor (EGF). In ER-negative breast cancer cultures $5 \mu \mathrm{mol} / \mathrm{I}$ genistein negated the stimulatory effects of TGF- $\alpha$, IGF-I and IGF-II, implying the inhibition of tyrosine kinase activity [23]. The human EGF receptor-2 oncogene (Her-2) is constitutively overexpressed in approximately 30\% of breast cancers and is associated with a poor patient prognosis [71]. Research using breast cancer cell lines suggests that dietary phyto-oestrogens are capable of repressing EGF receptor activity. The inhibition of tyrosine kinase activity by $5 \mu \mathrm{mol} / /$ genistein in MCF- 7 cells correlated with the repression of EGF receptor tyrosine phosphorylation in response to EGF stimulation [23]. Similar findings were reported in a recent study investigating the chemoprotective effects of the green tea polyphenol epigallocatechin-3 gallate (EGCG). The treatment of Her-2/ neu over-expressing mouse mammary cells with $20-80 \mu \mathrm{g} / \mathrm{ml}$ EGCG inhibited proliferation in a dose-dependent manner, correlating with a reduction in Her-2/neu signalling activity [72]. The basal tyrosine phosphorylation of Her-2/neu was decreased by approximately $96 \%$ following treatment with 
$80 \mu \mathrm{g} / \mathrm{ml}$ EGCG. Downstream activities of the signalling proteins phosphoinositide 3-kinase, Akt and nuclear factor$\kappa B$ were similarly repressed, suggesting a potential clinical application of EGCG in breast cancer therapy.

The soy isoflavones have additionally been proposed to regulate the proliferation of breast epithelia via an alternative mechanism involving the modulation of TGF- $\beta$ synthesis [73]. In normal mammary tissue TGF- $\beta$ maintains proliferative homeostasis by inhibiting the growth of epithelial cells $[74,75]$. The incubation of human mammary epithelial cells with $5 \mu \mathrm{mol} / \mathrm{l}$ genistein induced a fivefold increase in the level of TGF- $\beta$ secretion [76]. The further analysis of media conditioned with human mammary epithelial cells revealed the presence of the active as opposed to latent form of TGF- $\beta$, thus implying a direct link between soy isoflavones and the TGF- $\beta$ signalling pathway.

\section{Conclusion}

This review highlights current ambiguities regarding the precise role of phyto-oestrogens in breast cancer chemoprevention. Phyto-oestrogens were originally proposed as cancer protective agents following epidemiological observations revealing a low breast cancer incidence in soy-consuming populations. However, later research failed to ascertain a preventive role of phyto-oestrogens in breast cancer, possibly because of lack of long-term human dietary intervention trials. Although existing shortterm studies do suggest an association between phytooestrogen consumption and a favourable steroid hormone profile, the precise effects on mammary cell proliferation remain unclear. The apparent lack of proliferative effects in adult dietary trials may be explained by both rodent studies and retrospective dietary recall studies, which suggest that breast cancer chemoprevention during adulthood is critically dependent on the prior consumption of phyto-oestrogens during adolescence. The physiological effects of phyto-oestrogens may be further influenced by additional factors such as ER expression status within the mammary tissue, precise quantities of phyto-oestrogens ingested and the ability to produce active metabolites.

Although the role of dietary phyto-oestrogens in breast cancer chemoprevention remains inconclusive, rodent studies encouragingly suggest that soy products may possess antitumour activities. Mammary tumours in phytooestrogen-fed rodents typically develop with an increased latency period, are smaller in size, are better differentiated and have a reduced capacity for metastasis. Perhaps the most clinically promising data concern the ability of phytooestrogen compounds to inhibit the proliferation of ERnegative breast cancer cultures and tumour xenografts in rodents. Although ER-positive cells are often growth stimulated by low phyto-oestrogen concentrations, stimulatory effects have not been reported in cells devoid of functional
ER. Phyto-oestrogen compounds may thus potentially prove to be clinically useful for the treatment of ERnegative breast tumours that are typically unresponsive to traditional tamoxifen hormonal therapy. Although current data regarding self-medication with phyto-oestrogens by breast cancer patients remain controversial, the published literature does imply that these compounds may prove to be promising agents for future use in cancer therapy. Clinical trials are warranted to compare the efficacy of phyto-oestrogens with that of conventional endocrine therapies, and to assess their efficacy as alternatives to HRT to alleviate menopausal symptoms. The latter is especially pertinent given that the premature termination of the HABITS (Hormonal Replacement Therapy After Breast Cancer - Is It Safe?) trial [77] may lead to increased phyto-oestrogen use.

\section{Competing interests}

None declared.

\section{Acknowledgement}

JLL is funded by a grant from the World Cancer Research Fund.

\section{References}

1. Messina MJ: Legumes and soybeans: overview of their nutritional profiles and health effects. Am J Clin Nutr 1999, Suppl: 439S-450S.

2. Barnes S: Phytoestrogens and cancer. Baillières Clin Endocrinol Metab 1998, 12:559-579.

3. Lamartiniere CA: Protection against breast cancer with genistein: a component of soy. Am J Clin Nutr 2000,Suppl:1705S$1707 \mathrm{~S}$.

4. Dai Q, Shu X-O, Jin F, Potter JD, Kushi LH, Teas J, Gao Y-T, Zheng W: Population-based case-control study of soyfood intake and breast cancer risk in Shanghai. $\mathrm{Br} J$ Cancer 2001, 85:372-387.

5. Wu AH, Ziegler RG, Nomura AMY, West DW, Kolonel LN, HornRoss PL, Hoover RN, Pike MC: Soy intake and risk of breast cancer in Asians and Asian Americans. Am J Clin Nutr 1998 Suppl:1437S-1443S.

6. Adlercreutz H: Phyto-oestrogens and cancer. Lancet Oncol 2002, 3:364-373.

7. Cassidy A, Hanley B, Lamuela-Raventos RM: Isoflavones, lignans and stilbenes - origins, metabolism and potential importance to human health. J Sci Food Agric 2000, 80:10441062.

8. Setchell KDR, Radd S: Soy and other legumes: 'bean' around for a long time but are they the 'superfoods' of the millennium and what are the safety issues for their constituent phytoestrogens? Asia Pacific J Clin Nutri 2000, Suppl:S13-S22.

9. Benassayag C, Perrot-Applanat M, Ferre F: Phytoestrogens as modulators of steroid action in target cells. J Chromatogr $B$ Analyt Technol Biomed Life Sci 2002, 777:233-248.

10. Le Bail J-C, Champavier Y, Chulia A-J, Habrioux G: Effects of phytoestrogens on aromatase, $3 \beta$ and $17 \beta$-hydroxysteroid dehydrogenase activities and human breast cancer cells. Life Sci 2001, 66:1281-1291.

11. Rosenberg Zand RS, Jenkins DJA, Diamandis EP: Steroid hormone activity of flavonoids and related compounds. Breast Cancer Res Treat 2000, 62:35-49.

12. Tamir S, Eizenberg M, Somjen D, Stern N, Shelach R, Kaye A, Vaya J: Estrogenic and antiproliferative properties from licorice in human breast cancer cells. Cancer Res 2000, 60: 5704-5709.

13. Tham DM, Gardner CD, Haskell WL: Potential health benefits of dietary phytoestrogens: a review of the clinical, epidemiological and mechanistic evidence. J Clin Endocrinol Metab 1998, 83:2223-2235. 
14. Burow ME, Boue SM, Collins-Burow BM, Melnik LI, Duong BN, Carter-Wientjes $\mathrm{CH}$, Li S, Wiese TE, Cleveland TE, McLachlan JA: Phytochemical glyceollins, isolated from soy, mediate hormonal effects through estrogen receptor $\alpha$ and $\beta$. J Clin Endocrinol Metab 2001, 86:1750-1758.

15. Franke $A A$, Custer $L J$, Tanaka $Y$ : Isoflavones in human breast milk and other biological fluids. Am J Clin Nutr 1998, Suppl: 1466S-1473S

16. McMichael-Philips DF, Harding C, Morton M, Roberts SA, Howell A, Potten CS, Bundred NJ: Effects of soy-protein supplementation on epithelial proliferation in the histologically normal human breast. Am J Clin Nutr 1998, Suppl:1431S-1436S.

17. Hargreaves DF, Potten CS, Harding C, Shaw LE, Morton MS, Roberts SA, Howell A, Bundred NJ: Two-week dietary soy supplementation has an estrogenic effect on normal premenopausal breast. J Clin Endocrinol Metab 1999, 84: 4017-4024.

18. Lu L-J W, Anderson KE, Grady JJ, Kohen F, Nagamani M: Decreased ovarian hormones during a soya diet: implications for breast cancer prevention. Cancer Res 2000, 60:4112-4121.

19. Maskarinec G, Williams AE, Inouye JS, Stanczyk FZ, Franke AA: A randomised isoflavone intervention among premenopausal women. Cancer Epidemiol Biomarkers Prev 2002, 11:195-201.

20. Morton MS, Arisaka O, Miyake N, Morgan LD, Evans AJ: Phytoestrogen concentrations in serum from Japanese men and women over forty years of age. J Nutr 2002, 132:3168-3171.

21. Bowers JL, Tyulmenkov VV, Jernigan SC, Klinge CM: Resveratrol acts as a mixed agonist/antagonist for estrogen receptors $\alpha$ and $\boldsymbol{\beta}$. Endocrinology 2000, 141:3657-3667.

22. Routledge EJ, White R, Parker MG, Sumpter JP: Differential effects of xenoestrogens on coactivator recruitment by estrogen receptor (ER) $\alpha$ and ER $\beta$. J Biol Chem 2000, 275:3598635993.

23. Fioravanti L, Cappelletti V, Miodini P, Ronchi E, Brivio M, Di Fronzo G: Genistein in the control of breast cancer cell growth: insights into the mechanism of action in vitro. Cancer Lett 1998, 130:143-152.

24. Peterson TG, Ji G-P, Kirk M, Coward L, Falany CN, Barnes S: Metabolism of the isoflavones genistein and biochanin $\mathrm{A}$ in human breast cancer cell lines. $A m$ J Clin Nutr 1998, Suppl:1505S-1511S.

25. Doostdar H, Burke MD, Mayer RT: Bioflavonoids: selective substrates and inhibitors for cytochrome P450 CYP1A and CYP1B1. Toxicology 2000, 144:31-38.

26. Potter GA, Patterson LH, Wanogho E, Perry PJ, Butler PC, ljaz T, Ruparelia KC, Lamb JH, Farmer PB, Stanley LA, Burke MD: The cancer preventative agent resveratrol is converted to the anticancer agent piceatannol by the cytochrome P450 enzyme CYP1B1. Br J Cancer 2002, 86:774-778.

27. McFadyen MCE, Breeman S, Payne S, Stirk C, Miller ID, Melvin WT, Murray Gl: Immunohistochemical localisation of cytochrome P450 CYP1B1 in breast cancer with monoclonal antibodies specific for CYP1B1. J Histochem Cytochem 1999, 47: 1457-1464.

28. Maubach J, Bracke ME, Heyerich A, Depypere HT, Serreyn RF, Mareel MM, de Keukeleire D: Quantitation of soy-derived phytoestrogens in human breast tissue and biological fluids by high-performance liquid chromatography. J Chromatogr $B$ Analyt Technol Biomed Life Sci 2003, 784:137-144.

29. Peeters PHM, Keinen-Boker L, van der Schouw YT, Grobbee DE: Phytoestrogens and breast cancer risk. Breast Cancer Res Treat 2003, 77:171-183.

30. Kumar NB, Cantor A, Allen K, Riccardi D, Cox CE: The specific role of isoflavones on estrogen metabolism in premenopausal women. Cancer 2002, 94:1166-1174.

31. Duncan AM, Merz-Demlow BE, Xu X, Phipps WR, Kurzer MS: Premenopausal equol excretors show plasma hormone profiles associated with lowered risk of breast cancer. Cancer Epidemiol Biomarkers Prev 2000, 9:581-586.

32. Grube BJ, Eng ET, Kao Y-C, Kwon A, Chen S: White button mushroom phytochemicals inhibit aromatase activity and breast cancer cell proliferation. J Nutri 2001, 131:3288-3293.

33. Lu L-J W, Cree M, Josyula S, Nagamani M, Grady JJ, Anderson $\mathrm{KE}$ : Increased urinary excretion of 2-hydroxyestrone but not $16 \alpha$-hydroxyestrone in premenopausal women during a soya diet containing isoflavones. Cancer Res 2000, 60:1299-
34. Key TJ, Sharp GB, Appleby PN, Beral V, Goodman MT, Soda M, Mabuchi K: Soya foods and breast cancer risk: a prospective study in Hiroshima and Nagasaki, Japan. Br J Cancer 1999, 81:1248-1256.

35. Horn-Ross PL, John EM, Lee M, Stewart SL, Koo J, Sakoda LC Shiau AC, Goldstein J, Davis P, Perez-Stable EL: Phytoestrogen consumption and breast cancer risk in a multiethnic population. Am J Epidemiol 2001, 154:434-441.

36. Shu XO, Jin F, Dai Q, Wen W, Potter JD, Kushi LH, Ruan Z, Gao Y-T, Zheng W: Soyfood intake during adolescence and subsequent risk of breast cancer among Chinese women. Cancer Epidemiol Biomark Prev 2001, 10:483-488.

37. Lamartiniere CA: Timing of exposure and mammary cancer risk. J Mammary Gland Biol Neoplasia 2002, 7:67-76.

38. Lamartiniere CA, Zhang J-X, Cotroneo MS: Genistein studies in rats: potential for breast cancer prevention and reproductive and developmental toxicity. Am J Clin Nutr 1998, Suppl: 1400S-1405S

39. Banerjee S, Bueso-Ramos C, Aggarwal BB: Suppression of 7,12-dimethyl(a)anthracene-induced mammary carcinogenesis in rats by resveratrol: role of nuclear factor- $\mathrm{KB}$, cyclooxygenase 2 and matrix metalloprotease 9. Cancer Res 2002, 62: 4945-4954.

40. Jin Z, MacDonald RS: Soy isoflavones increase latency of spontaneous mammary tumours in mice. J Nutr 2002, 132: 3186-3190.

41. Bhat KPL, Lantvit D, Christov K, Mehta RG, Moon RC, Pezzuto JM: Estrogenic and antiestrogenic properties of resveratrol in mammary tumour models. Cancer Res 2001, 61:7456-7463.

42. Gallo D, Giacomelli S, Cantelmo F, Zannoni GF, Ferrandina G, Fruscella E, Riva A, Morazzoni P, Bombardelli E, Mancuso S, Scambia G: Chemoprevention of DMBA-induced mammary cancer in rats by dietary soy. Breast Cancer Res Treat 2001, 69:153-164.

43. Constantinou Al, Krygier AE, Mehta RR: Genistein induces maturation of cultured human breast cancer cells and prevents tumour growth in nude mice. $A m J$ Clin Nutr 1998, Suppl:1426S-1430S.

44. Yan L, Li D, Yee JA: Dietary supplementation with isolated soy protein reduces metastasis of mammary carcinoma cells in mice. Clin Exp Metastas 2002, 19:535-540.

45. Jordan VC: Long-term adjuvant tamoxifen therapy for breast cancer. Breast Cancer Res Treat 1990, 15:126-136.

46. Morrow M, Jordan VC: Tamoxifen for the prevention of breast cancer in high-risk women. Ann Surg Oncol 2000, 7:67-71.

47. Marsden J: The menopause, hormone replacement therapy and breast cancer. J Steroid Biochem Mol Biol 2002, 83:123132.

48. Chiechi LM: Hormone replacement therapy and health protection. Curr Opin Investig Drugs 2003, 4:439-443.

49. Wuttke W, Jarry H, Westphalen S, Christoffel V, Seidlova-Wuttke D: Phytoestrogens for hormone replacement therapy? Steroid Biochem Mol Biol 2002, 83:133-147.

50. Messina MJ, Loprinzi CL: Soy for breast cancer survivors: a critical review of the literature. J Nutr 2001, Suppl:3095S-3108S.

51. This $P$, De la Rochefordière A, Clough K, Fourquet A, Magdelenat $\mathrm{H}$ : Phytoestrogens after breast cancer. Endocr Relat Cancer 2001, 8:129-134.

52. Ju YH, Doerge DR, Allred KF, Allred CD, Helferich WG: Dietary genistein negates the inhibitory effect of tamoxifen on growth of estrogen-dependent human breast cancer (MCF-7) cells implanted in athymic mice. Cancer Res. 2002, 62:2474-2477.

53. Schwartz JA, Liu G, Brooks SC: Genistein-mediated attenuation of tamoxifen-induced antagonism from estrogen receptor-induced genes. Biochem Biophy Res Commun 1998, 253: 38-43.

54. Tanos V, Brzezinski A, Drize O, Strauss N, Peretz T: Synergistic inhibitory effects of genistein and tamoxifen on human dysplastic and malignant epithelial breast cells in vitro. Eur J Obstet Gynecol Reprod Biol 2002, 102:188-194.

55. Hall JM, Couse JF, Korach KS: The multifaceted mechanisms of estradiol and estrogen receptor signaling. J Biol Chem 2001 276:36869-36872

56. Hsu J-T, Hung H-C, Chen C-J, Hsu W-L, Ying C: Effects of the dietary phytoestrogen biochanin A on cell growth in the mammary carcinoma cell line MCF-7. J Nutr Biochem 1999, 10:510-517. 
57. Maggiolini M, Bonofiglio D, Marsico S, Panno ML, Cenni B, Picard $D$, Ando S: Estrogen receptor $\alpha$ mediates the proliferative but not the cytotoxic dose-dependent effects of two major phytoestrogens on human breast cancer cells. Mol Pharmacol 2001, 60:595-602.

58. Dampier K, Hudson EA, Howells LM, Manson MM, Walker RA, Gescher A: Differences between human breast cell lines in susceptibility towards growth inhibition by genistein. $\mathrm{Br} J$ Cancer 2001, 85:618-624.

59. Upadhyay S, Neburi M, Chinni SR, Alhasan S, Miller F, Sarkar FH: Differential sensitivity of normal and malignant breast epithelial cells to genistein is partly mediated by p21WAF1. Clin Cancer Res 2001, 7:1782-1789.

60. Nomoto $S$, Arao $Y$, Horiguchi H, Ikeda K, Kayama F: Oestrogen causes $G_{2} / M$ arrest and apoptosis in breast cancer MDA-MB231. Oncol Rep 2002, 9:773-776.

61. Morito K, Aomori T, Hirose T, Kinjo J, Hasegawa J, Ogawa S, Inoue $S$, Muramatsu M, Masamune $Y$ : Interaction of phytoestrogens with estrogen receptors $\alpha$ and $\beta$ (II). Biol Pharm Bull 2002, 25:48-52.

62. An J, Tzagarakis-Foster C, Scharschmidt TC, Lomri N, Leitman DC: Estrogen receptor $\beta$-selective transcriptional activity and recruitment of coregulators by phytoestrogens. J Biol Chem 2001, 276:17808-17814

63. Liu J, Burdette JE, Xu H, Gu C, van Breemen RB, Bhat KPL Booth A, Constantinou Al, Pezzuto JM, Fong HHS, Farnsworth $\mathrm{NR}$, Bolton JL: Evaluation of estrogenic activity of plant extracts for the potential treatment of menopausal symptoms. J Agric Food Chem 2001, 49:2472-2479.

64. Petterson K, Delaunay F, Gustafsson J-A: Estrogen receptor $\beta$ acts as a dominant regulator of estrogen signaling. Oncogene 2000, 19:4970-4978.

65. Gehm BD, McAndrews JM, Chien P-Y, Jameson JL: Resveratrol, a polyphenolic compound found in grapes and wine, is an agonist for the estrogen receptor. Proc Natl Acad Sci USA 1997, 94:14138-14143

66. Levenson AS, Gehm BD, Pearce ST, Horiguchi J, Simons LA, Ward JE, Jameson JL, Jordan VC: Resveratrol acts as an estrogen receptor (ER) agonist in breast cancer cells stably transfected with ER- $\alpha$. Int J Cancer 2003, 104:587-596.

67. Leung LK, Wang TT: Bcl-2 is not reduced in the death of MCF-7 cells at low genistein concentration. J Nutri 2000, 130:29222926.

68. Po LS, Chen Z-Y, Tsang DSC, Leung LK: Baicalein and genistein display differential actions on estrogen receptor (ER) transactivation and apoptosis in MCF-7 cells. Cancer Lett 2002, 187:33-34.

69. Pozo-Guisado E, Alvarez-Barrientos A, Mulero-Navarro S, SantiagoJosefat B, Fernandez-Salguero PM: The antiproliferative activity of resveratrol results in apoptosis in MCF-7 but not in MDA-MB231 human breast cancer cells: cell-specific alterations of the cell cycle. Biochem Pharmacol 2002, 64:1375-1386.

70. Vergote D, Cren-Olive C, Chopin V, Toillon R-A, Rolando C, Hondermarck H, Le Bourhis X: (-)-Epigallocatechin (EGC) of green tea induces apoptosis of human breast cancer cells but not of their normal counterparts. Breast Cancer Res Treat 2002, 76: 195-201.

71. Masood S, Bui MM: Prognostic and predictive value of HER2/ neu oncogene in breast cancer. Microsc Res Tech 2002, 59: 102-108.

72. Pianetti S, Guo S, Kavanagh KT, Sonenshein GE: Green tea polyphenol epigallocatechin-3 gallate inhibits Her-2/Neu signalling, proliferation and transformed phenotype of breast cancer cells. Cancer Res 2002, 62:652-655.

73. Kim H, Peterson TG, Barnes S: Mechanisms of action of the soy isoflavone genistein: emerging role for its effects via transforming growth factor $\beta$ signalling pathways. $A m$ J Clin Nutr 1998, Suppl:1418S-1425S.

74. Sovak MA, Arsura M, Zanieski G, Kavanagh KT, Sonenshein GE: The inhibitory effects of transforming growth factor- $\beta 1$ on breast cancer cell proliferation are mediated through regulation of aberrant nuclear factor- $\mathrm{kB} / \mathrm{rel}$ expression. Cell Growth Differ 1999, 10:537-544.

75. Knabbe C, Lippman ME, Wakefield LM, Flanders KC, Kasid A, Derynck R, Dickson RB: Evidence that transforming growth factor- $\beta$ is a hormonally regulated negative growth factor in human breast cancer cells. Cell 1987, 48:417-428.
76. Kim H, Xu J, Su Y, Xia H, Li L, Peterson G, Murphy-Ullrich J, Barnes $S$ : Actions of the soy phytoestrogen genistein in models of human chronic disease: potential involvement of transforming growth factor- $\beta$. Biochem Soc Trans 2001, 29: 216-222.

77. Holmberg L, Anderson H: HABITS (hormonal replacement therapy after breast cancer - is it safe?), a randomised comparison: trial stopped. Lancet 2004, 363:453-455.

\section{Correspondence}

Valerie Speirs, Molecular Medicine Unit, University of Leeds, St James's University Hospital Leeds LS9 7TF, UK. E-mail v.speirs@leeds.ac.uk 